\title{
Radical-Nationalist Podcasting under a Post-Fascist Condition
}

\author{
The Swedish Podcast Motgift
}

\author{
Tomas Poletti Lundström | ORCID: 0000-0002-9500-6274 \\ Centre for Multidisciplinary Studies on Racism, Uppsala University, \\ Uppsala, Sweden \\ tomas.lundstrom@teol.uu.se
}

\author{
Markus Lundström | ORCID: 0000-0003-3579-2143 \\ Centre for Multidisciplinary Studies on Racism, Uppsala University, \\ Uppsala, Sweden \\ markus.lundstrom@cemfor.uu.se
}

\begin{abstract}
This article sketches fascism's ideological morphology under a post-fascist condition. It builds empirically on three years of ethnographic studies of the radical-nationalist podcast Motgift [Antidote], disclosing that (i) fascist multivocality characterizes and feeds the rhizomic structure of Swedish radical nationalism; (ii) fascist narration locates protagonists and antagonists in driving a plot of 'genocide against the white race'; and (iii) fascist temporality reinforces ideas of a lost past and degenerated present - prompting a struggle for cultural rebirth and racial revival. The multivocality, narration, and temporality of Motgift illuminate the radical-nationalist politics at work under a post-fascist condition: the state of ideological reconfiguration pondering fascism's historical downfall.
\end{abstract}

\section{Keywords}

Sweden - podcasts - Motgift - post-fascism - radical nationalism - ethnography rhizome - temporality

In popular discourse, the term fascism is commonly used as a designation for authoritarian rule or as a pejorative accusation of political 
opponents. ${ }^{1}$ To avoid this reductive understanding, scholars have instead used, alongside the influential notion of a generic fascism, ${ }^{2}$ a host of alternative conceptualizations: radical right, ${ }^{3}$ far right, ${ }^{4}$ right-wing extremism, ${ }^{5}$ ultra-nationalism, ${ }^{6}$ radical nationalism, ${ }^{7}$ and white nationalism. ${ }^{8}$ Scholarly understandings of fascism range from maximalist to minimalist definitions, ${ }^{9}$ distinguish between war/interwar fascism and neo-fascism, ${ }^{10}$ include revolutionary and counterrevolutionary taxonomies, ${ }^{11}$ and encompass Marxist as well as Weberian approaches. ${ }^{12}$ Fascism has been understood as a historically distinct phenomenon, as 'Fascism' (with a capital 'F') established in the 1920 s in Italy under Mussolini. ${ }^{13}$ But it has also been approached as a trans-historical

1 Roger Griffin, Fascism: An Introduction to Comparative Fascist Studies (Cambridge: Polity, 2018), 6-7.

2 Robert O. Paxton, The Anatomy of Fascism (New York: Vintage, 2007); Kevin Passmore, Fascism: A Very Short Introduction (New York: Oxford University Press, 2014).

3 Jens Rydgren, 'The Sociology of the Radical Right,' Annual Review of Sociology 33 (2007): 241-262.

4 Peter Davies and Derek Lynch, The Routledge Companion to Fascism and the Far Right (London: Routledge, 2002).

5 Elisabeth Carter, 'Right-Wing Extremism/Radicalism: Reconstructing the Concept,' Journal of Political Ideologies 23 (2018): 157-182, https://doi.org/10.108o/13569317.2018.1451227.

6 Mattias Gardell, 'Urban Terror: The Case of Lone Wolf Peter Mangs,' Journal of Terrorism and Political Violence 30 (2018): 793-811, https://doi.org/10.108o/o9546553.2018.1444796.

7 B. R. Teitelbaum, Lions of the North: Sounds of the New Nordic Radical Nationalism (Oxford: Oxford University Press, 2017); Markus Lundström and Tomas Lundström, 'Hundra år av radikal nationalism,' Det vita fältet: Samtida forskning om högerextremism III Arkiv: Tidskrift för samhällsanalys, no. 5 (2016): 39-66, http://dx.doi.org/10.13o68/200o-6217.5.2.

8 Damon T. Berry, Blood and Faith: Christianity in American White Nationalism Syracuse University Press, 2017); Carol M. Swain, New White Nationalism in America: Its Challenge to Integration (Cambridge: Cambridge University Press, 2004).

9 Tamir Bar-On, Rethinking the French New Right: Alternatives to Modernity (London: Routledge, 2013).

10 Anna Cento Bull, 'Neo-Fascism,' in The Oxford Handbook of Fascism, ed. R.J.B. Bosworth, (Oxford: Oxford University Press, 2010),; Nigel Copsey, 'Changing Course or Changing Clothes? Reflections on the Ideological Evolution of the British National Party 1999-2006,' Patterns of Prejudice 41 (2007): 61-82, https://doi.org/10.108o/oo313220601118777.

11 Ruth Wodak and John E. Richardson, 'European Fascism in Talk and Text: Introduction,' in Analysing Fascist Discourse: European Fascism in Talk and Text, ed. Ruth Wodak and Jon E, Richardson (New York [etc.]: Routledge, 2012), 1-16.

12 Passmore, Fascism.

13 Gilbert Allardyce, 'What Fascism Is Not: Thoughts on the Deflation of a Concept,' The American Historical Review 84 (1979): 367-388, https://doi.org/10.2307/1855138; John Lukacs, The Hitler of History (New York: Knopf, 1997), 118; Zeev Sternhell, Mario Sznajder and Maia Ashéri, The Birth of Fascist Ideology: From Cultural Rebellion to Political Revolution (Princeton: Princeton University Press, 1994). 
phenomenon (lowercase 'fascism'). ${ }^{14}$ This latter observation has prompted understandings that fascism, too, is contextually adaptable and transformable over time. ${ }^{15}$

This article explores fascism's ideological plasticity by analyzing its function in a podcast promoting Swedish radical nationalism. Starting from Roger Griffin's notion that contemporary fascism typically undertakes a rhizomic structure, a 'cellular, centerless, and leaderless network with ill-defined boundaries and no formal hierarchy,'16 the rhizome of Swedish radical nationalism provides a fruitful entry point to study fascism in flux. As we have argued elsewhere, Swedish radical nationalism contains three currents that in various historical moments run parallel, intersect, merge, and diverge. ${ }^{17}$ The first current is race-oriented and often identifies with National Socialism. This current is generally distinguishable from a second, culture-oriented nationalism that today labels itself as social-conservative. The third current of Swedish radical nationalism is identity-oriented, typically connected to the identitarian movement(s) springing from the Nouvelle Droite [French New Right]. This has gained currency during the last decades by reconnecting the race-oriented and culture-oriented currents - which has been feeding the rhizome of Swedish radical nationalism.

The following analysis is theoretically inspired by Michael Freeden's morphological approach to ideology, ${ }^{18}$ which arguably represents one of the most vibrant developments in the field of ideology studies. ${ }^{19}$ Freeden herein defines

14 Matteo Albanese and Pablo Del Hierro, Transnational Fascism in the Twentieth Century: Spain, Italy and the Global Neo-Fascist Network (London: Bloomsbury Academic, 2016); Arnd Bauerkämper and Grzegorz Rossolinski, Fascism without Borders: Transnational Connections and Cooperation between Movements and Regimes in Europe from 1918 to 1945 (New York: Berghahn Books, 2017).

15 Aristotle A. Kallis, The Fascism Reader (London: Routledge, 2003); Roger Griffin with Matthew Feldman, ed., Fascism: Critical Concepts in Political Science. Vol 1-5 (London: Routledge, 2004).

16 Roger Griffin, 'Fascism's New Faces (and New Facelessness) in the "Post-Fascist" Epoch,' in A Fascist Century: Essays by Roger Griffin, ed. Matthew Feldman (Basingstoke: Palgrave Macmillan, 2008), 181-202.

17 Lundström and Lundström, 'Hundra år av radikal nationalism.'

18 See Roger Griffin, "The "Post-Fascism" of the Alleanza Nazionale: A Case Study in Ideological Morphology,' Journal of Political Ideologies 1 (1996): 123-145, https://doi. org/10.1080/13569319608420733; Ivan Gomza, 'Elusive Proteus: A Study in the Ideological Morphology of the Organization of Ukrainian Nationalists,' Communist and Post-Communist Studies 48 (2015): 195-207, https://doi.org/10.1016/j.postcomstud.2015.06.005.

19 See Iain Mackenzie, 'The Idea of Ideology,' in Political Ideologies: An Introduction, ed. Robert Eccleshall et al. (New York: Routledge, 2003), 1-16. 
ideologies as 'configurations of decontested meanings of political concepts.'20 In this theory, political concepts are inherently contested. It is the systematic fixation, or decontestation, of these concepts that constitutes an ideology; and specific interrelations between these concepts produce different ideologies. Freeden writes that political concepts acquire meaning through their 'particular structural position within a configuration of other political concepts.'21 He argues that constant negotiation and reconfiguration of political concepts form an ideological morphology, one that is dynamic, adaptable, and changeable over time. ${ }^{22}$ In the following pages, Freeden's approach is employed to analyze fascist reconfiguration in the radical-nationalist podcast Motgift.

\section{Motgift as an Ethnographic Field Site}

Methodologically, our analysis was inspired by recent developments in digital anthropology, and refined into a method we call 'podcast ethnography'. This method, which we have launched and detailed elsewhere, ${ }^{23}$ was here applied to study the radical-nationalist podcast Motgift as an ethnographic field site.

Podcast ethnography starts from the observation that the podcast medium digitally broadcasted conversations between two or more speakers - has grown substantially over the past two decades. ${ }^{24}$ It approaches the podcast as a participatory medium; podcast hosts frequently interact with their perceived audience through social media platforms, web-fora, and email correspondence. ${ }^{25}$ Podcast ethnography, then, focuses on the relational interaction between speakers and listeners as joint participants in a particular sphere of interest, community, or subculture. ${ }^{26}$ In the podcast interface, primary

20 Michael Freeden, Ideologies and Political Theory: A Conceptual Approach (Oxford: Clarendon Press, 1996), 76.

21 Ibid., 4.

22 Michael Freeden, Ideology: A Very Short Introduction (Oxford: Oxford University Press, 2003).

23 Markus Lundström and Tomas Poletti Lundström, 'Podcast ethnography,' International Journal of Social Research Methodology, published ahead of print 1 July 2020, https://doi.org/ 10.1080/13645579.2020.1778221.

24 Monica Chadha, Alex Avila and Homero Gil De Zúñiga, 'Listening In: Building a Profile of Podcast Users and Analyzing Their Political Participation,' Journal of Information Technology \& Politics 9 (2012): 388-401; Tal Samuel-Azran, Tal Laor and Dana Tal, 'Who Listens to Podcasts, and Why? The Israeli Case,' Online Information Review 43 (2019): 482-495, https:// doi.org/10.1108/OIR-04-2017-0119.

25 Hayley Birch and Emma Weitkamp, 'Podologues: Conversations Created by Science Podcasts,' New Media \& Society 12 (2010): 889-9o9.

26 Richard Berry, 'Part of the Establishment: Reflecting on 10 Years of Podcasting as an Audio Medium,' Convergence 22 (2016): 661-671; Sally Carlton, 'Producing Human Rights Memory: 
speakers (hosts) give voice to secondary speakers (guests, listeners). This interactive character of the podcast thereby fosters an optimal climate for exchange and negotiation of ideas.

Although much research has documented fascist activities in new social media, ${ }^{27}$ including the Swedish context, ${ }^{28}$ the podcast medium remains understudied in this regard. ${ }^{29}$ This prompted us to embark upon a podcast ethnography that lasted for nearly three years, the time required to reach a workable level of empirical saturation. In terms of data collection, we listened to each episode when released online, in order to enable us to pause, rewind, and adjust the play-back speed. Select episodes, those particularly dynamic in ideological morphology, were downloaded for in-depth analysis. The coding procedure involved identification of episode metadata, primary and secondary speakers, invited guests, and listener comments. We also coded memos and analytical notes taken while listening, guided by the sensibility and rigor defined by the art of producing ethnographic field notes. ${ }^{30}$ In the final step of the analysis, the codes were refined, clustered, and conceptualized, in order to sketch out three particular features of fascism's ideological morphology in Motgift.

Analysis of an "Everyday Human Rights" Radio Show/Podcast,' Journal of Human Rights Practice 10 (2018): 355-366, https://doi.org/10.1093/jhuman/huyo16.

27 Manuela Caiani, 'Radical Right Cross-National Links and International Cooperation,' in The Oxford Handbook of the Radical Right, ed. Jens Rydgren (New York: Oxford University Press, 2018); Ofra Klein and Jasper Muis, 'Online Discontent: Comparing Western European FarRight Groups on Facebook, European societies 21 (2019): 540-562; Christian Fuchs, 'Fascism 2.o: Twitter Users' Social Media Memories of Hitler on His 127th Birthday,' Fascism 6 (2017): 228-263, https://doi.org/10.1163/22116257-0o6o20o4; Manuela Caiani and Linda Parenti, European and American Extreme Right Groups and the Internet (New York: Routledge, 2016).

28 Mattias Ekman, 'You Tube Fascism: Visual Activism of the Extreme Right,' in Totalitarian Arts: The Visual Arts, Fascism(S) and Mass-Society, ed. Mark Epstein, Fulvio Orsitto and Andrea Righi (Newcastle upon Tyne: Cambridge Scholars Publishing, 2017), 350-373; Ralf Wiederer, Mapping the Right-Wing Extremist Movement on the Internet: Structural Patterns 2006-2011 (Wien: LIT Verlag, 2013); Mattias Ekman, 'Anti-Refugee Mobilization in Social Media: The Case of Soldiers of Odin,' Social Media + Society 4 (2018): 1-11.

29 To our knowledge, only two studies have been published with this empirical focus: Tina Askanius, 'Studying the Nordic Resistance Movement: Three Urgent Questions for Researchers of Contemporary Neo-Nazis and Their Media Practices,' Media, Culture \& Society 41 (2019): https://doi.org/10.1177/o163443719831181; Per-Erik Nilsson, 'The Crocodile and the Gardener: Swedish Radical Nationalism and Critique of Religion,' in A Constructive Critique of Religion: Encounters between Christianity, Islam and Non-Religion in Secular Societies, ed. Mia Lövheim and Mikael Stenmark (London: Bloomsbury, 2020), 124-134.

30 See Robert Emerson, Rachel Fretz and Linda Shaw, Writing Ethnographic Fieldnotes (Chicago: University of Chicago Press, 2011), 18; David Fetterman, Ethnography: Step-by-Step (London: SAGE, 2010), 116-120. 
Motgift [Antidote] was for several years an influential think-tank in the rhizome of Swedish radical nationalism. It was rooted in the organization Nationalsocialistisk front [National Socialist Front], which was founded in 1994 but later reorganized to enter parliamentary politics under the name Svenskarnas parti [Party of the Swedes]. In December 2011, the party published the first issue of its new official organ Framåt [Forward]. A few months later, three of the recurrent writers, among them a party board member, initiated the affiliated podcast project Radio Framåt. In February 2014, it was relaunched under the name Motgift, a small media nexus encompassing a publishing house, a web-magazine, and a series of podcasts published alongside its main vehicle: a weekly, two-hour long podcast airing every Monday (the prime focus of our analysis). It closed down in March 2018 when its key members founded the organization Det Fria Sverige [The Free Sweden], with its own dedicated podcast. Hence, the central position of Motgift during these years - as a leading forum for discussing Swedish radical nationalism across organizational boundaries - empirically motivates an analysis of its relation to the ideological morphology of fascism.

\section{The Ideological Morphology of Fascism}

In the podcast Motgift, fascism was at once denounced, deployed, and developed. Our empirical analysis suggests that interactions between Motgift's primary and secondary speakers designate three distinct features of ideological morphology: fascist multivocality, fascist narration, and fascist temporality.

\section{Fascist Multivocality}

The plethora of voices and ideological positions - fascist multivocality was a signatory feature of Motgift. The podcast took the form of a talk show, with topics often connected to contemporary events and news affecting the radical-nationalist universe. The key host of the show was Dan Eriksson (b. 1982), previously active as leader in the youth wing of the political party Nationaldemokraterna [The National Democrats] and as a board member of above mentioned Svenskarnas parti. The former was founded in 2001 after a fragmentation within the culture-oriented, radical-nationalist party Sverigedemokraterna [The Sweden Democrats]. From the start, Eriksson worked together with Magnus Söderman (b. 1977), previously a leading member and political theorist of the race-oriented organization Svenska motståndsrörelsen [Swedish Resistance Movement, later Nordic Resistance Movement]. As a key individual of Swedish radical nationalism since the early 199os, 
Söderman cultivated relations with American actors like Brüders Schweigen [The Order] and Aryan Nations. ${ }^{31}$ Söderman left Svenska motståndsrörelsen after an internal conflict in 2011. Beside Eriksson and Söderman, author and activist Jonas De Geer (b. 1971) was the third initial co-host of Motgift. At the outset of his career, De Geer was inspired by radical conservatism and perennial philosophy, and later contributed texts to the identity-oriented website Motpol [Antipode]. ${ }^{32} \mathrm{He}$ has written for various radical-nationalist organizations, and he wrote the foreword to the Swedish translation of Jewish racism, authored by influential American white nationalist and former Ku Klux Klan leader David Duke. Aside from the original Motgift-trio - Eriksson, Söderman, and De Geer - a fourth primary speaker came to join Motgift: Björn Björkqvist (b. 1979), a former key figure of Nationalsocialistisk front and local politician in Svenskarnas parti.

Although Motgift was from the start affiliated to Svenskarnas parti, the relationship eventually grew more porous. The podcast's four hosts, all experienced figures in different parts of the radical-nationalist rhizome, discussed a variety of political issues independent of organizational ties. This enabled them to develop ideological concepts and pursue novel relational connections, both domestic and international; a significant number of guests were invited to participate as discussants in the podcast. Some of these secondary speakers, for example Daniel Friberg (b. 1978) and Marcus Follin (b. 1989), were especially important and repeatedly invited. (Friberg is the founder and chief editor of Arktos Media, an influential publishing house in the international 'alt-right' environment. Follin, also known under his internet nickname The Golden One, is a social media influencer who combines body building with radical-nationalist agitation). Both Friberg and Follin have gained authority in the trans-Atlantic nationalist exchange of ideas. For example, Friberg was for a period closely linked to Richard Spencer (b. 1978), who popularized the term 'alt-right.' Moreover, a host of additional speakers were invited as guests to the podcast, including key figures from USA, UK, Greece, Italy, Belgium and Denmark.

This diversity of the secondary speakers, representing a wide range of ideational positions, seems to have established Motgift as a vanguard forum for developing radical-nationalist thought in Sweden. Our excursions into the Motgift web-forum indicate that listeners also consumed several

31 Mattias Gardell, Gods of the Blood: The Pagan Revival and White Separatism (Durham, N.C.: Duke University Press, 2003), 229.

32 Tomas Lundström, 'Let Us Build an Ark!':Jonas De Geer and the Negotiation of Religion within Radical Nationalism (Master's Thesis: Uppsala University, 2016). 
other podcasts from various currents of Swedish radical nationalism. In a comment-thread on Motgift's web-forum, spanning from May 2015 to September 2017, thirty-five podcasts were mentioned more than once. The four most common were the culture-oriented, radical-nationalist podcasts Radio Länsman (unaffiliated) and Ingrid \& Conrad (unaffiliated), the race-oriented Radio Nordfront (Nordic Resistance Movement), and the identity-oriented Motpol podcast. Motgift also seems to have functioned as a transnational node connecting disparate organizations such as Vlaams Belang (Belgium), Golden Dawn (Greece), Forza Nuova (Italy), British National Party (UK), National Youth Front (USA) and Nordic Resistance Movement (Sweden/Norway/Finland/ Denmark), alongside leading ideology producers such as Derek Holland, author of the influential 'Third Position' pamphlet The Political Soldier, and Greg Johnson, author and editor of Counter Currents Publishing. ${ }^{33}$ These individuals as well as other organizational representatives were invited as honored guests. In line with fascist narration in Motgift - the plot of an ongoing genocide against the white race - guest speakers were presented as allies in a pan-nationalist resistance struggle.

But Motgift was also, like the radical-nationalist milieu at large, marked by interpersonal tensions and hostility, organizational disruptions, and splits. A recurrent tension was the heated discussion during Donald Trump's 2016 presidential campaign. ${ }^{34}$ Primary speaker De Geer forcefully criticized other radicalnationalists for endorsing Trump, while the prominent guest Daniel Friberg, and even the podcast key host Eriksson, fiercely argued the opposite standpoint. Symptomatic of the internal conflicts between even the primary speakers, De Geer was eventually banned from the podcast over accusations of having an affair with Björkqvist's partner. ${ }^{35}$ Motgift was eventually closed

33 See Mattias Gardell, Heléne Lööw and Michael Dahlberg-Grundberg, Den Ensamme Terroristen: Om Lone Wolves, näthat och brinnande flyktingförläggningar (Stockholm: Ordfront, 2017); Graham Macklin, 'Greg Johnson and Counter-Currents,' in Key Thinkers of the Radical Right: Behind the New Threat to Liberal Democracy, ed. Mark Sedgwick (Oxford: Oxford University Press, 2019).

34 'Debatt om Donald Trump,' Motgift, episode 181, November 16, 2015; 'Gotlandgate och hur Donald Trumpade i klaveret,' Motgift, episode 284, October 10, 2016; 'Greg Johnson on the Alt-Right, Donald Trump and a White Future', Motgift, episode 286, October 13, 2016. Today many of the Motgift episodes have gone offline, mainly due to the closing of the website, which makes them inaccessible for the general public. At the time of writing this article, some episodes from 2016-2018 were still available at the Motgift YouTube-channel: https:// www.youtube.com/user/motgiftnu.

35 Magnus Söderman and Dan Eriksson, 'Jonas De Geer inte längre en del av Motgift,' Motgift, May 29, 2017, www.motgift.nu/2017/05/29/jonas-de-geer-inte-langre-en-del-av-motgift/, accessed June 21, 2019. 
down soon after this interpersonal debacle. Yet its fascist multivocality sustained throughout its four years of intense broadcasting, in spite of both personal and ideational tensions. Why?

\section{Fascist Narration}

Our examination suggests that Motgift was able to manufacture a connection between protagonists and antagonists within a larger fascist narration. The podcast was marked by the idea of an antagonistic 'Jewish power', operating as a political force against the (protagonistic) interests of 'Europe', 'the Swedes', or 'the white race'. This antagonistic force prompted two interconnected threats: one external - represented by ideas like 'the great replacement [folkutbytet]' and 'the refugee invasion' - the other internal, represented by ideas of political treason, loss of family values, and overall cultural decadence following promotion of 'sexual perversions. ${ }^{36}$ In the Motgift narrative, 'Jewish Power' operated on both of these fronts:

[De Geer:] Before [the War], Germany was probably the place in the world where Jews led the most easy lives and flourished. But then ... they created this aversion against themselves that eventually led to Hitler. That's something you need to look at to understand this.

[Björkqvist:] Yes, and it was the same thing in Austria. Vienna was really a perverse city, with a lot of sexual distortion and so on. And normal people reacted against this. It's not surprising that people were critical of Jews, or even tarred everyone with the same brush, considering that Jews were often involved in these perversions. When people speak about the Kristallnacht and state that it was horrible because there was shattered glass everywhere, one could ask how there could have been shattered glass everywhere if the Jews didn't happen to own everything? ${ }^{37}$

The historical accounts in this excerpt illustrate the antagonistic force at once posing an internal threat, the 'perversions' of Vienna, and an external threat through Jewish establishment in Germany. Hence, the underscoring plot of a mutual enemy ('Jewish Power'), and its modus operandi ('replacement', 'perversion'), seems to function as common ground to bridge ideational divisions;

36 'Mass invasion' has also been a central topic in the Nordic Resistance Movement's website Nordfront. See Christer Mattsson and Thomas Johansson, Life Trajectories Into and Out of Contemporary Neo-Nazism: Becoming and Unbecoming the Hateful Other (Abingdon: Routledge, 2019), 62-79.

37 'Vad spelar ras för roll?' Motgift, episode 288, October 17, 2016. 
the multivocality of Motgift was engendered by faith-based ideas of a common 'we' as a protagonist counterpart to 'Jewish Power':

[De Geer:] People had respect for God and for religion, even if they weren't candidly pious ... Except for the Pentecostals perhaps. But one doesn't need to be pious to appreciate the value in all that.

[Söderman:] Like you've mentioned before, we need faith. And we need faith that is militant, that is masculine, and that declares what needs to be done loud and clear. Not like the Pope, or the archbishops, or the disgusting ecumenical people - but a faith, a leadership stating that 'God wants you to battle, God wants you to fight.'38

Motgift's primary speakers discuss in this excerpt the 2016 Normandy church attack (in which a Catholic priest was murdered). Their emotionally intense conversation leads to the conclusion that a revived 'respect for God and for religion' could rebuild the disunited radical-nationalist milieu in Sweden. In line with the key fascist idea of a reinforced, new man rising from the ashes of cultural degeneration, ${ }^{39}$ Söderman calls for a 'militant' and 'masculine' faith that incites people to join the radical-nationalist cause. This protagonist - a faith-based force defending the white race in Europe - was recurrent in Motgift's fascist narration. Quite illustratively, the episodes typically closed with Under Svea banér, a Swedish hymn written by theologian Samuel Ödmann in the early 180os: 'Under the banner of Svea / Heaven grants us victory / Then for King and Land / Honor raises its hand.'

This fascist narration depicts how the white race, under a God-given, nationalist banner, eventually unites to reclaim and rebuild its lost homeland. In Motgift, this faith-based protagonist served to bypass the radical-nationalist schism between proponents of Norse paganism and Christianity. ${ }^{40}$ Söderman, who during different periods of his career affiliated with 'Christian Identity' as well as Norse paganism, ${ }^{41}$ celebrated Christians and heathens joining forces: ${ }^{42}$ 'I see heathens stating "this time we fight together". I see this everywhere, and

38 'Deus Vult!' Motgift, episode 26o, July 26, 2016.

39 Passmore, Fascism; Paxton, The Anatomy of Fascism.

40 Gardell, Gods of the Blood; Christoffer Kølvraa, 'Embodying "the Nordic Race": Imaginaries of Viking Heritage in the Online Communications of the Nordic Resistance Movement,' Patterns of Prejudice 53 (2019): 270-284, https://doi.org/10.1080/oo31322X.2019.1592304.

41 Gardell, Gods of the Blood, 228-230; see also Magnus Söderman, 'Den mörka religionen,' Nordfront, February 27, 2008, www.nordfront.se/den-morka-religionen.smr, accessed May 29, 2020.

42 'Deus Vult!. 
I do believe in this revival.' This belief in a present struggle for racial revival seems to entail its own, fascist temporality.

\section{Fascist Temporality}

Motgift had quite a cognizant use of history in its narration of struggle for cultural rebirth. Recalling collective memories of a distant past included conversations about Italian Fascism and German National Socialism. Although the Motgift speakers labeled their ideology in terms of 'nationalism', pledging allegiance to 'the national movement', they typically set out to correct supposed misunderstandings of fascism and 'Nazism'. In a scornful chat about the Swedish Prime Minister Stefan Löfven calling The Sweden Democrats a 'neo-fascist' political party, De Geer declared that Löfven's lack of historical knowledge exemplified, as he put it, an ominous intellectual decay, 'so damn bad at this point that it's time for revolution. 43 In De Geer's reading, Swedish culture and leadership was in such decay that only rebirth, re-evolution, could bring about a brighter future.

Motgift's fascist temporality encompassed a proud but lost past followed by a degenerated present, craving struggle for a revived future. Collective memories, historical imaginaries of past resistance against cultural decay, were significant in this fascist temporality. And these recollections interlinked closely with the notion of 'defeatism'. In an episode focused on the 2017 presidential election in France, Motgift's primary speakers dwelled upon, and argued strongly against, other nationalists' despairing reception of En Marche's victory over Front National. Söderman accordingly contrasted his afflicted allies with the life of Belgian National Socialist collaborator and Rexist leader Léon Degrelle:

He [Degrelle] saw his whole world ravaged. And he wasn't alone, there were many others. They didn't sit down to say 'now it's done, now everything is crap, now there's nothing more to do.' They spoke about glory and honor, and they continued to fight. I don't want to hear that damn rubbish, frankly, given the sacrifices that have been made by men and women in our history.... People dare to say 'now it's over because it went like this.' What the hell? Just stop it! Nonsense! ${ }^{44}$

This excerpt illustrates how historical events, in this case from the 1940s, were recollected in discussions of contemporary issues. Söderman here emphasizes 
that defeated National Socialists, after the fall of the Third Reich, did not give up hope or quit fighting. He revisits this alleged persistence as a collective memory, in order to discredit fellow nationalists that express resignation over Front National's loss of the French election. His argument, as articulated later in the same episode, is confirmed and expanded by Eriksson:

I want to return to what we talked about earlier, about defeatism and lack of history. There is a remarkable focus ... on the parliamentary. On elections, to win elections.... In Germany, there has for a long time now existed an expression about 'the fight for the streets, the minds, and the parliaments.' ... Thus, first the streets; being able to secure freedom of expression, being able to protest. But also [securing] areas, and thereby also being able to influence people's minds. ... This is metapolitics, to bring about cultural change, a change of attitude. This is followed by parliamentary success. If one is to choose which of these is least important, then it's really the parliamentary. Because that's just a consequence of other things happening in society. ${ }^{45}$

The three-part expression of 'the fight for the streets, the minds, and the parliaments', as stated by Eriksson in this excerpt, clearly draws on identitarian ideas. Eriksson's mention of metapolitics is an explicit reference to ideas connected to the Nouvelle Droite emphasis on cultural rather than political struggle. ${ }^{46}$ At the same time, these three areas - streets, minds, and parliaments - are all connected to one of fascism's political concepts: struggle. When fighting is more important than winning, struggle becomes a defining feature of fascist temporality. 'Defeatism' then becomes a derogatory term. The disdain for 'defeatism' here taps into a historical tradition of reproaching deserters of the fascist struggle. (Perhaps most notably expressed by the Wehrkraftzersetzung decree through which 'defeatism' was criminalized in the Third Reich $)^{47}$. The disdain for 'defeatism' also functions to contradict the historiography of fascism losing in the mid-1940s; it is in this vein that Söderman recollects the memory of Léon Degrelle as a paragon that never gave in to pacifying feelings of defeat.

45 Ibid.

46 Roger Griffin, 'Interregnum or Endgame? The Radical Right in the "Post-Fascist” Era,' Journal of Political Ideologies 5 (2000): 163-178; Roger Griffin, 'Between Metapolitics and Apoliteia: The Nouvelle Droite's Strategy for Conserving the Fascist Vision in The "Interregnum", Modern \& Contemporary France 8 (2000): 35-53.

47 Steven Welch, 'Securing the German Domestic Front in the Second World War: Prosecution of Subversion before the People's Court,' Australian Journal of Politics \& History 53 (2007): $44-56$. 
Fascist temporality also had a negotiated and contestable quality in Motgift. The primary speakers discussed how the past should inspire the present, as in the discussion concerning the term 'alt-right', in which Söderman drew a parallel between the 'alt-right' and the Swedish proto-fascist movement Unghögern [The Young Right] of the early 19oos:

[Söderman:] I've always thought that the alt-right, from a Swedish perspective, stand closer to the old Unghöger. That it's this direction we should move towards. But that's probably because I myself want us to tread a little more towards that direction.

[De Geer:] That doesn't feel very relevant today, I must say.

[Söderman:] A national, conservative... a national value-conservative idea with a social thought, doesn't that feel relevant today?

[De Geer:] Yes, and no. At the same time, we're in such totally different situation today. The old Unghöger didn't have to confront the multicultural society. But we have to. It didn't have to confront this massive, systematic, cultural dissolution; the dissolution of norms with imposed acceptance of homosexuality and other perversities. So it's a completely different situation. Certainly we can get inspiration from it in some sense, just as you can draw inspiration from the nationalist movements of the 1930's and so on. But we must probably remember that we're in a completely different situation. We need new ways.

[Eriksson:] We need an alternative right.

[Björkqvist:] But we still have to look at the past, and I think Unghögern is a much better alternative to look at than the Swedish National Socialists for example. ${ }^{48}$

In this excerpt, Söderman's comparison of 'alt-right' and Unghögern builds on the assumption that historical phenomena can be linked to contemporary issues. Yet Söderman also considers that this idea could be mere wishful thinking due to his own bias. Nevertheless, the 'alt-right' becomes a projection for his hopes in a fascist future - which prompts the parallel to Unghögern. This future-oriented projection is confirmed by Eriksson's statement that 'we need an alternative right.' In contrast, De Geer hesitates about the need for clear inspiration from past phenomena since he finds the contemporary condition, 'the multicultural society', much more severe and difficult to confront. He therefore suggests a more eclectic stimulus from various past phenomena. This idea is picked up by Björkqvist, who remarks that Unghögern is actually one

48 ‘Är alt-right all-right?' Motgift, episode 345, March 13, 2017. 
such movement of inspiration, at least as a better inspiration than the 'Swedish National Socialists'. This conversation also exhibits the negotiated nature of fascism's ideological morphology in Motgift; different collective memories and historiographical views were promoted as inspiration for the present struggle. Overtly displayed disagreement and agreement, critique and revision, were commonplace throughout the podcast. Our argument is that Motgift's dynamic reconfiguration of fascism is indicative of a certain societal condition.

\section{Conclusion: The Post-Fascist Condition}

In the podcast Motgift, a central forum for Swedish radical nationalism in the late 2010s, fascist ideology was summoned to infuse the present struggle for future revival. Motgift recollected what Griffin points out as fascism's core concepts: 'populist ultra-nationalism and the myth of rebirth. ${ }^{49}$ In Motgift, the ideological morphology of fascism was characterized by a multivocality that allowed for disparate views and internal tensions among both primary and secondary speakers. The multivocality enabled Motgift to include a broad variety of domestic and international guests from different ends of the radical-nationalistic rhizome. Motgift's multivocality was powered by its narration of interrelated antagonistic and protagonistic forces; the prevalent idea of antagonistic 'Jewish Power' was contrasted with protagonistic radicalization of the Christian faith. The narrative plot of 'genocide against the white race' produced a conflictual set-up that allowed for ideational friction without risking rupture - it pinned antagonistic and protagonistic forces to a fascist storyline of constant struggle. Accompanying this narrative was a temporality with a utopian past and revived future divided by a degenerate present; a temporality aiming to, as Griffin has it, 'transform the linearity of decadence into the cyclic scheme of rebirth. ${ }^{50}$ Hence, multivocality, narration, and temporality stand out as key features in Swedish reconfigurations of fascism's ideological morphology. And these features become particularly meaningful, we argue, when fascism is bound to operate in the shadows, that is, under a post-fascist condition.

This conceptualization of post-fascism builds on the critical theorization of post-raciality: a societal condition in which racism is popularly perceived

49 Griffin, 'The "Post-Fascism" of the Alleanza Nazionale,' 128.

50 Roger Griffin, 'Fixing Solutions: Fascist Temporalities as Remedies for Liquid Modernity,' Journal of Modern European History 13 (2015): 5-23. 
as a past historical error or as individual outbursts of asocial behavior, despite the fact that people continue to experience structural racism. ${ }^{51}$ Whereas the 'post-racial' designates how racism thrives despite being publicly defeated (much like the 'post-colonial'), post-fascism encapsulates a condition where fascism is reconfigured with regard to its historical downfall. ${ }^{52}$ Others have noted that the concept of post-fascism highlights the 'adaptive qualities of fascism to historical and external forces, ${ }^{13}$ and that post-fascism is characterized by fluidity and variegation, 'just as contemporary anarchism and Marxism are multi-stranded and both continuous yet iterative variations upon their nineteenth and twentieth century antecedents. ${ }^{54}$ However, this latter comparison is faltering on one important point: adherents of post-anarchism and post-Marxism typically set out to advance their ideological traditions, and not to disassociate from them. ${ }^{55}$ Post-fascism, by contrast, gains momentum in an era without self-ascribed fascists - but with ideological reconfiguration in the 'demise of conspicuous fascism'. ${ }^{56}$ This opacity stipulates the post-fascist condition in a double sense: the noun 'condition' denotes both a prerequisite and a mode of being. ${ }^{57}$ The prerequisite for a post-fascist condition is fascism's springtime in the 1920 s through the 1940s, as well as its marginalized position in the post-war era. The social unfeasibility to self-identify as a fascist therefore requires a certain mode of being for the would-be adherents of this ideology. In this regard, the prefix 'post' indicates both continuation and discontinuation with historical fascism; contemporary actors 'both orientate towards and simultaneously deny' fascist ideology. ${ }^{58}$

51 Sherrow O Pinder, Colorblindness, Post-Raciality, and Whiteness in the United States (Cham: Springer, 2015); David Theo Goldberg, Are We All Postracial Yet? (Cambridge: Polity, 2015); David Theo Goldberg, The Threat of Race: Reflections on Racial Neoliberalism (Malden: Wiley-Blackwell, 2009). Chamsy El-Ojeili, 'Reflecting on Post-Fascism: Utopia and Fear,' Critical Sociology 45 (2018): 1149-1166.

53 Roel Reyes, 'Antebellum Palingenetic Ultranationalism: The Case for Including the United States in Comparative Fascist Studies,' Fascism: Journal of Comparative Fascism Studies 8 (2019): 307-330, https://doi.org/10.1163/22116257-0o8o2005.

54 El-Ojeili, 'Reflecting on Post-Fascism,' 1157.

55 See Saul Newman, Postanarchism (Cambridge: Polity Press, 2016); Ernesto Laclau and Chantal Mouffe, Hegemony and Socialist Strategy: Towards a Radical Democratic Politics (London: Verso, 2001).

56 Tamir Bar-On, Where Have All the Fascists Gone? (Burlington, VT: Ashgate, 2007).

57 Oxford English Dictionary, 'Condition, N.' (Oxford: Oxford University Press, 2020).

$5^{8}$ Wodak and Richardson, 'European Fascism in Talk and Text.' 
The post-fascist condition requires the multivocality, narration, and temporality enacted in Motgift. In this radical-nationalist podcast, the fascist ideology was at once denounced, deployed and developed: fascism was denounced as an historical failure, deployed to approach contemporary social issues, and developed for further applicability. This very ambiguity and fluidity is emblematic of fascism's ideological reconfigurations under a post-fascist condition.

\section{Acknowledgements}

We would like to thank Mattias Gardell, Heléne Lööw, Brian D. Williams, Anthony Fiscella, and Jonathan Leman, for their critical readings and useful comments on this text. 